\title{
Introducing Underrepresented Minority High School Students to an Aeronautical Technology Program at Purdue University
}

\author{
Ronald Sterkenburg, David L. Stanley \\ Purdue University
}

\begin{abstract}
The Purdue Aviation Technology Department developed an introductory aviation course for students participating in the six weeks Upward Bound rising sophomore program. Upward Bound is a pre-college preparatory program providing academic support, personal counseling and cultural enrichment for eligible low income and potential first-generation college participants in the East Chicago, Gary, Hammond, and the Lake Station target area. The goal of the introductory aviation course was to interest young people in the aviation industry, which is traditionally underrepresented by minorities. The students were exposed to all three components of the Aviation Program: Flight training, maintenance technology and business management. They were introduced to aerodynamics, propulsion, airframe structures and aircraft systems. A qualified pilot taught them the basics of flying a B-727 full motion flight simulator, and they made a flight in a light aircraft. As a final hands-on project the students built an aluminum winglet section. Last summer the faculty organized field trips to a major air carrier maintenance facility and an Air Force museum. The authors will discuss in this paper the unique challenges of developing a curriculum that attracts young minority students and the teaching strategies to overcome the cultural differences between minority students and faculty.
\end{abstract}

\section{Overview of the Upward Bound program}

Since 1966, Purdue University Calumet has hosted an Upward Bound program developed to improve the educational opportunities of first generation participants from low-income families in an area east of Chicago in northern Indiana referred to as "the Region". First generation participants are defined as those students whose parents do not have a four-year college degree. The demographics of the target area indicate a relatively high concentration of ethnic minorities and urban populations. The Region has a large high school drop out rate, up to $50 \%$ in some areas, and a high unemployment rate among the minority groups. The number of people with a four-year college degree in the region is well below the state and national average. Thirteen high schools participate in the program, and Upward Bound is funded to serve 120 first generation low-income students. Of this number, $1 / 3$ of the students are either low income or first generation, while $2 / 3$ are both low income and first-generation students. At the present time 73 students are enrolled, and it is anticipated that the goal of 120 students will be reached at the beginning of the summer of 2002.

Primary goals of the program are: High school academic success, effective preparation for postsecondary education, and eventual graduation from college. The students will be enrolled in the program during their last three years in high school. The program consists of two components: a nine-month academic year program - during which the students will attend classes every Saturday morning at the Purdue Calumet campus to reinforce and supplement high school

"Proceedings of the 2002 American Society for Engineering Education Annual Conference \& Exposition Copyright (C) 2002, American Society for Engineering Education” 
offerings - and three summer components. During their first summer, the rising sophomores will participate in a three weeks intensive session that will focus on Math, Science, English and foreign language skills. At the end of the session, students will have received approximately seventy hours of academic instruction. During their second summer, the rising juniors will participate in a seven weeks residential summer program at Purdue University's West Lafayette campus. The students will take courses in foreign language, mathematics concepts and applications, advanced topic in mathematics, writing, introduction to biological sciences, and introduction to technology and magazine production. The students have a full-day schedule with four 75-minutes classes, and scheduled mandatory study sessions between 6:30 and 8:30 PM. During this summer period, the students will live in the residence hall under the guidance of resident advisors. For the final summer session, the rising seniors will have the opportunity to experience the demands of learning on a non-residential, commuter campus. The students will take classes at the Purdue Calumet campus, which is located in the target area, while they live at home. The University stimulates participation by waving all student fees and tuition in order to give every student the opportunity regardless of financial status. Given three courses from which to choose, Communication, Psychology, and College Algebra, each student will select and enroll in two and will earn up to six hours of college credit.

In addition to the first three years, there is an optional eight-week Bridge summer program for graduating students. The intent of the bridge program on the West Lafayette Campus is to prepare students for the fall semester and make all necessary arrangements to assist in the adaptation and integration into the campus community. Each student who participates in the full sequence of the program will experience: one residential summer, two nonresidential summers, three academic years, and an optional bridge summer.

\section{College enrollment and completion}

The number of Upward Bound graduates enrolled in College is encouraging, as illustrated in table 1 .

\begin{tabular}{|l|c|}
\hline Students attending College & $100 \%$ \\
\hline Students attending Indiana University & $25 \%$ \\
\hline Students attending Purdue University & $35 \%$ \\
\hline Students attending Purdue Calumet University & $30 \%$ \\
\hline Students attend out-of-state universities or other Indiana colleges & $10 \%$ \\
\hline Students graduating from college (tracked since 1996) & $80 \%$ \\
\hline
\end{tabular}

\section{Table 1}

In view of the statistic relative to college enrollment and success for students in the Region, these statistical data reflect the remarkable success of the Upward Bound program. 


\section{Introduction to Aviation Technology}

Both authors of this paper taught the introductory course in Aviation Technology last summer, and are scheduled to teach next summer again. The remainder of this paper will focus on the importance of teaching an aviation technology course for minority students. The Aviation Technology course is part of the seven-week residential program for the rising juniors at the Purdue University West Lafayette Campus.

In the past, aviation had a romantic attraction for many young people. If you had asked young students what they wanted to become in life, many would have answered pilot. That is not necessarily true anymore; young people are not as enthusiastic about aviation and airplanes as we were. Often times, young people seem to be more attracted to computers and related technologies. This may be accounted for by the fact that these technologies are rapidly changing and improving, while aviation has undergone painful growth and adaptation of late as a result of near-capacity operation. As a result, the airline industry continues to experience a shortage of both pilots and technicians, but it becomes harder to find qualified people. Over the years, the airline industry has traditionally attracted the white male, while females and minorities have always been underrepresented in this industry. Demographical information for this industry is not readily available, as the Federal Aviation Authority (FAA) does not compile such data; they only differentiate between the numbers of male and female employees. While airline companies may have the statistical information, they too are reluctant to release it. Although such information could be useful in quantifying the extent of the problem, apparently the industry is concerned that publication of the data may be problematical, for one reason or another. In discussions with personnel at a major airline company, we learned that the company has set a goal of employing at least 35\% minorities, but they would not share the exact numbers they employ right now with us. From data provided by the US Air Force for similar jobs in the armed forces, we learned that, for instance, about $10 \%$ of the aircraft mechanics in the Air Force are African-American.

It is the opinion of the authors that people from all demographic backgrounds have talents and skills important to the aviation industry. Sound information on race, ethnic background, and gender is very helpful as efforts are made to understand the statistical disparity that exists for this industry. As we attempt to interest young people in an aviation career, it is a worthy goal to reach across the boundaries of race, ethnicity, and gender and extend to these groups the opportunities that are available. It is time to increase the pool of potential interested students.

\section{Aviation curriculum}

Last year we introduced a revised curriculum for the introductory course in Aviation for the rising juniors of Upward Bound. It was our plan to give the students a broad view of the aviation industry. The program was divided in three main areas: Aviation Maintenance Technology, Aviation Management, and Flight Technology. These main topical areas are outlined in table 2. 


\begin{tabular}{|c|c|c|}
\hline $\begin{array}{l}\text { Aviation Maintenance } \\
\text { Technology }\end{array}$ & Flight technology & Business administration \\
\hline - Aircraft structures & - Principles of flight & $\begin{array}{l}\text { - Air traffic control } \\
\text { system }\end{array}$ \\
\hline - Powerplant and systems & - Simulator operation & - Airport operations \\
\hline - Electrical systems & - Aerodynamics & \\
\hline - Aerodynamics and stability & & \\
\hline
\end{tabular}

\section{Table 2}

The authors came to the conclusion that lecturing students in a classroom at this age is not effective, and, furthermore, they tend to experience this as a punishment. Our main goal was for students to have fun and enjoy themselves, with the idea that some might eventually pursue a career in the aviation industry. We chose a very hands-on approach, and introduced the lecture topics during the actual hands-on activity. In this way the students stayed focused and were able to directly relate the lecture material to the practical projects.

The students were introduced to aircraft structures and their final project was to build a winglet section of aluminum alloy. They practiced and mastered techniques such as measuring, drilling, sheet metal forming, riveting and welding. During the propulsion sessions, they were introduced to aircraft reciprocating and turbine engines. They were involved in test runs of engines and the balancing procedures of a propeller. By far the most popular part of the course was the two-hour session in a B-727 full motion flight simulator during which the students had the opportunity to fly the simulator and perform take-offs and landings. A Purdue University flight instructor demonstrated many different flight scenarios and enabled students to gain a better understanding of simulator education and training. Afterwards two students asked what they needed to do to become an airline pilot. All students were also given an opportunity to make a 30-minute flight in a small single engine airplane, and this experience also evoked interest in flight training on the part of several students. The pilot, a Purdue University instructor and retired airline pilot, demonstrated the basic concepts of flight and gave the students a visual tour of the local area from the air. To give the students a good idea about the industry and career opportunities, we organized field trips to the airport traffic control tower at Purdue Airport, the United Airlines maintenance center in Indianapolis and the Air Force museum at Grissom Air Force base.

\section{Next year's one-project theme approach}

After our first year, both faculty members felt that we need to develop the curriculum around one central theme, which could function as a vehicle to explain the principals of flight, aircraft construction, and propulsion systems. The proposed theme should be challenging and interesting. An article by MIT describing the construction of a Lighter than Air Vehicle (LAV), which was published in the journal of Engineering Education motivated us to develop a similar project for use in the Upward Bound program. MIT uses the concept of building the LAV in freshmen engineering courses; similarly, we would like to use it for the Upward Bound students. The LAV would be the perfect vehicle to explain the concepts of lift, weight, buoyancy, stability, propulsion, electrical controls, and vehicle construction techniques. The Aviation Department has all or most of the equipment and materials required with the exception of weather balloons 
and helium. The weather balloons will function as the primary lifting bodies, and aluminum alloys will be used to construct the vehicle. Due to the relatively high weight of the aluminum, the students will be charged with the task of reducing weight as necessary in order for the vehicle to fly with the available lift and propulsion. A four-channel radio will be used to control the servos and motors.

At the beginning of the course, the group of students will be divided in two groups of 6 students each, and the final goal will be to fly the LAVs in a competitive race inside the basketball stadium. Due to the limited practical exposure to technology, the instructors will participate and help guide the process. On the first day, we will explain the rules of the competition to the students, and the next day we will start to build the vehicle. The schedule then calls for time to be spent daily in explanation and discussion of the theories and processes involved. The students will work approximately 75 minutes on the project each day, and ideally one night per week both teams will meet at the same time to have a time period of 3 hours total. The students are expected to study the theoretical concepts during the scheduled night study sessions. We hope to share our findings and experiences of next summer's program at a latter date.

\section{Background of the students}

Ten of the forty Upward Bound students participating in last year's program were enrolled in the introductory aviation course. There were three female and seven male students. Nine of the remaining students were African-American and one student was Hispanic. They all grew up in a relatively poor urban area, and were potential first-generation college participants. It became apparent after initial interviews that they grew up under quite different circumstances. School shootings, metal detectors at school, a high crime rate and drugs in neighborhoods and schools were very common occurrences in their lives. The majority of the students were raised in a single-family household (80\%). The students were selected from 13 high schools in the "region" and had been with the Upward Bound program for two years.

\section{Interaction with the students}

The age group and cultural/ethnic background of this group was totally different from the typical group of freshmen students entering the Aviation Program at Purdue. The demographics of the aviation program for the last two years were: $90 \%$ white, $5 \%$ female, and $5 \%$ minorities. Our main challenge for this Upward Bound group was how to motivate them and to offer them an interesting experience that could persuade them to go to college.

Upward Bound uses a small class size to improve teacher-student interaction. We found that the female students in general were more motivated and interested in the course than the male students, except maybe for the flight simulator session. After initial interviews with the students many mentioned that the teachers in their schools didn't care about teaching and about them. So there was some distrust on their part towards teachers, and it was our task to change that view. It took a few days to break the ice. The small class size facilitates the development of positive relationships with the students, and allows time for students to talk about their lives and their futures. Even if the students don't choose a career in the aviation field it is very important to share life experiences with them and help them become aware of the many and varied 
opportunities available in college. The field trips were an excellent way to improve the faculty/student interaction. Traveling together on a bus, listening to the radio and share lunch in a restaurant is a good way to break the ice and build trust and respect. We found that there was a substantial difference in the behavior of the female and male students. The female students were more motivated and serious. They were also superior in the hands-on sheet metal structure project. The male students seemed to be more influenced by peer pressure and were still showing signs of adolescent behavior - acting as boys needing a little guidance and time to become men.

\section{Conclusion}

The large majority of the Upward Bound students will enroll in College and a substantial number will graduate. The Upward Bound program gives underrepresented students an opportunity to go to college and become successful in their lives. The number of Upward Bound students enrolling in the Aviation Department is small, but the effort during the seven weeks rising sophomores is very useful. The main objective of the Upward Bound program is to interest students to go to College and graduate. If our efforts can stimulate these students to improve their chances in life regardless of what college program they choose, our mission will be fulfilled.

Bibliographic information

Valtierra, J., and Berry C., Upward Bound at Purdue University Calumet Hammond, Indiana, Upward Bound Proposal, 1995-1999.

United States Air force, Minorities in the aviation maintenance field, HTTP://www.afpc.randolph.af.mil, 2001

Newman, D., and Amir, R., Innovative First Year Aerospace Design Course at MIT, journal of engineering education, July 2001.

Biographical information

RONALD STERKENBURG: Professor Sterkenburg teaches aerospace structures courses at the Aviation Technology Department at Purdue University. He was born and raised in the Netherlands and has lived in the United States since 1996. He has a strong interest in minority education and equal opportunity for students of all races.

DAVID STANLEY: Professor Stanley teaches powerplant technology courses in the Aviation Technology Department at Purdue University. In addition to education credentials and experience relating directly to his area of teaching, he also holds a degree in secondary education, and is very interested in supporting the development of students who are striving to overcome barriers to success.

"Proceedings of the 2002 American Society for Engineering Education Annual Conference \& Exposition Copyright (C) 2002, American Society for Engineering Education” 